\title{
Team Teaching and the Application in the Course English Teaching Methodology by CET and NSET in China
}

\author{
Dianjian Wang \\ Lanzhou Jiaotong University \\ 88 West Anning Road Lanzhou Jiaotong University \\ 201 Mailbox, Lanzhou 730070, China \\ Tel: 86-931-495-6156 E-mail:wangdianjian@msn.com
}

\begin{abstract}
Based on the experiences of team teaching the course English Teaching Methodology to 2 classes of adult in-service teachers in a teacher training university in China for one year, this paper intends to discuss the background and the concept of the term team teaching, summarize the models of the team teaching, how the models of team teaching was applied in the course English Teaching Methodology and its implication to EFL teaching, and provide team teachers with specific tips on how to teach collaboratively and effectively as equal partners in the same EFL classroom.
\end{abstract}

Keywords: Team teaching, Co-plan, Co-presentation

\section{Introduction}

Team teaching is a strategy that has been used across U.S high school at all levels and for different purposes since 1960s. In recent years, team-taught courses have become an important part of the university curriculum in America (Anderson, \& Landy, 2006).

Historically, team teaching has been seen as a practice suited for gaining better control of large groups of students (Ivins, 1964) or, in some cases, as a method for prescribing teacher actions (York, 1971).Occasionally, it has been appreciated as a way to inject variety into the traditional single-subject, subject-teacher classroom (Vars,1969). More recently, collaborative teaching has been situated in the context of school improvement (Jacobs, 1999) and inter-and intrapersonal knowledge as important considerations in team teaching has been examined (Collinson, 1999).

Though team teaching has been around for years, but most of the research is about the education for the exceptional children, the tips and strategies of successful team teaching, the models and types of team teaching in the general education. As for the team teaching practice in EFL, few of the articles or books can be found.

We (Wang, the Chinese English teacher (CET) and Liz, the native speaking English teacher (NSET)) team taught the course English Teaching Methodology to 2 classes of adult in-service teachers in a teacher training university in China for one year. Based on our experiences and the definitions and models of team teaching, this paper summarizes how we team taught the course English Teaching Methodology and its implication to EFL teaching, and provides team teachers with details on how to teach collaboratively and effectively as equal partners in the same EFL classroom.

\section{Definitions and models of team teaching}

Team teaching can be defined as a group of two or more teachers working together to plan conduct and evaluate the learning activities for the same group of learners. Quinn and Kanter (1984) defined team teaching as "simply team work between two qualified instructors who, together, make presentation to an audience." Davis (1995) noted all team teaching efforts "include two or more faculty in some level of collaboration in the planning and delivery of a course.". Team teaching implies two broad categories: one is that two or more instructors are teaching the same students at the same time within the same classroom. This implies that each speaks freely during large-group instruction and moves among all the students in the class.; the other is that the instructors work together but do not necessarily teach the same groups of students nor necessarily teach at the same time.

Sharon (1997) identified several alternative models of co-teaching: A: One Group: one lead teacher, one teacher "teaching on purpose"; B: Two Groups: Two teachers teach same contents; C: Two groups: One teacher re-teaches, one teacher teaches alternative information; D: Multiple Groups: Two teachers monitor/teach; content may vary; E: One group: two teachers teach same content; Watkins and Caffarella (1999) identified four types of teams based on variations in working style: parallel teaching, serial teaching, co-teaching, and co-facilitation; Friend and Cook (2003) described more common approaches as One-Teach-One Support, One-Teach-One Drift, Alternative Teaching, Parallel Teaching, Station Teaching, and Team Teaching; Six models of team teaching have been identified by Robinson and Schaible (1995). 
-Traditional Team Teaching: In this case, the teachers actively share the instruction of content and skills to all students. For example, one teacher may present the new material to the students while the other teacher constructs a concept map on the overhead projector as the students listen to the presenting teacher.

Collaborative Teaching: This academic experience describes a traditional team situation in which the team teachers work together in designing the course and teach the material not by the usually monologue, but rather by exchanging and discussing ideas and theories in front of the learners. Not only so the team teachers work together, but the course itself uses group learning techniques for the learners, such as small-group work, student-led discussion and joint test-taking.

Complimentary/Supportive Team Teaching: This situation occurs when one teacher is responsible for teaching the content to the students, while the other teacher takes charge of providing follow-up activities on related topics or on study skills.

-Parallel Instruction: In this setting, the class is divided into two groups and each teacher is responsible for teaching the same material to her/his smaller group. This model is usually used in conjunction with other forms of team teaching, and is ideally suited to the situation when students are involved in projects or problem-solving activities, as the instructor can roam and give students individualized support.

-Differentiated Split Class: This type of teaching involves dividing the class into smaller groups according to learning needs .Each educator provides the respective group with the instruction required to meet their learning needs. For example, a class may be divided into those learners who grasp adding fractions and those who need more practice with the addition of fractions. One teacher would challenge the learners who grasped the concept more quickly, while the second teacher would likely review or re-teach those students who require further instruction.

-Monitoring Teacher: This situation occurs when one teacher assumes the responsibility for instructing the entire class, while the other teacher circulates the room and monitors student understanding and behavior..

\section{Application}

\subsection{Background}

Classes: Class A and Class B, Grade 03 in English department in Gansu Lianhe University, Lanzhou, China

Students: adult in-service teachers (most of them are the English teachers in the middle schools in Gansu province, China)

Major: English education

Course: English Teaching Methodology

Textbook: "A Course in English Language Teaching" by Wang Qiang, Chen Xiaotang Cheryl Moen and Bob Adamson

Team teachers: Wang, the CET, Chinese L1, English L2 and Liz, the NSET, English L1.

Time: 2003.9-2004.7

Models of team teaching: We tried all models mentioned in the above 2.section according to the contents we taught and types of class, not just select one of them.

\subsection{Instructional planning}

Planning is an integral part of any effective teacher's schedule and is a proactive way to determine what standards will be addressed. The core of team teaching is determining what instructional techniques will be most efficient and effective in helping all students meet those standards. One of the major benefits of team teaching is that teachers can bring different areas of expertise. These diverse skills are helpful during the planning stage, as both instructors' can find ways to use their strengths to ensure that the lesson is appropriately differentiated for a class. Many considerations must be reviewed before planning to do team teaching.

Firstly, the whole process of team teaching has to be planned. In order to ensure the planning work successfully, both team teachers need to get administrative support and the agreement of leaders in scheduling common planning periods, and permission to apply team teaching in certain courses, and must then schedule once or twice a week to use part of a period for planning. In our team teaching experience, an entire 90 -minutes period a day each week should be ample amount of time to plan the lessons for one or two weeks.

Secondly, carefully co-planned lesson plan must be completed. At the outset, we had to sit down and work out how we would divide up the syllabus. Taking one chapter per two-hour lesson was not feasible, because some chapters were longer than others, and some more important than others. We discussed this and then constructed a tentative plan, which we revised as we went along. We had a meeting to plan the lessons. This planning was vital for the success of our team teaching. 
Based on our experiences, we have identified several issues that team teachers should address when they are planning if they want to be successful:

- Whose classroom management rules do we use?

Most team teachers know the types of academic and social behavior they find acceptable and unacceptable. Over the years, both CET and NSET have established their own ways to deal with students' inappropriate behavior. Teachers should discuss their classroom management styles and the roles they expect of each other in maintaining a smoothly running classroom.

- What do we tell the students?

The students should be informed that they have two teachers and that both teachers have the same authority. In interviews we have conducted, many students who have participated in team teaching classrooms tell us that having two teachers is better because everyone gets more help and they can benefit from two teachers.

- How can we find time to co-plan?

The most pervasive concern of both teachers in team teaching situations is obtaining sufficient time during the school day to plan and discuss instruction and student progress. If a common planning period is not a possibility, explore other options, such as meeting during student activities, or meeting during regular lunch or after-school times. We sometimes found it difficult to find the time to plan lessons. We had to resort to meeting on the school bus, but we did manage to hold meetings regularly and successfully.

\subsection{Instructional presentation}

The actual process of teaching in the same classroom at the same time to the same students is often the most difficult component. However, instructional presentation is the most rewarding part of team teaching.

We took turns to do a warm-up exercise by the way of One-Teach-One Support at the beginning of the class. Then the first teacher would begin - according to what had been planned. CET preferred to do more of the theory and NSET handled more of the practical application and activities. While one was teaching, the other would also be standing in front of the class - maybe by the door or window. The idea was that the other teacher was free to add something when appropriate. The teaching teacher would occasionally ask the other to add an example or give an opinion, or at other times the non-teaching teacher would ask if they could add something. One has to be careful here as there is always a lot to add in methodology. It is easy for one teacher to take more than their allotted time. CET would sometimes use Chinese to explain, but seldom. If CET said something in Chinese, he told NSET what he was saying in English. CET presented the Chinese teaching methods - sometimes criticizing them and at other times saying he thought they were very appropriate in China. We demonstrated some methods together, such as singing, or actions. Even though this was the first time we'd ever done team teaching, we were very pleased with the lessons. We enjoyed the good relationship in the lessons and had fun teaching together. We even joked with each other a bit, which the students enjoyed. Teachers' interaction in presentation can also be regarded as a model of teaching for students to follow in their own future teaching, and it can also be as a learning opportunity for students.

\subsection{Assessment}

Assessing students to determine if they are learning and to identify what instructional changes may need to be made is an ideal area for collaboration. Both of us worked together to determine what was working instructionally for the whole class, and what areas may need revision or re-addressing. However, as with the other areas of team teaching, assessment requires that team teachers take time to discuss potential areas for concern or disagreement before they become a real issue. We wrote the exam paper together - CET concentrated on the parts he taught and NSET on the parts she taught. Then we each marked the parts we wrote, but discussed the marks and came to an agreement about the passes and failures.

\section{Implications}

In order to team teach successfully, language teachers need cooperation both in class and out of class. The followings are some implications of team teaching:

\subsection{Team-teaching personal relationship}

Team teachers' personal characteristics, common knowledge, and skills and attitudes will influence the process of team teaching.

- Team teachers should have personal characteristics that enable them to work effectively with another instructor.

- Team teachers should have sets of common knowledge and skills.

- Team teachers should have discipline-specific knowledge and skills.

- Team teaching should be voluntary. 


\subsection{The professional relationship}

Team teachers need to have unique professional relationships.

- The professional relationship is built on parity, communication, respect, and trust.

- Team teachers make a commitment to building and maintaining their professional relationship.

\subsection{Co-planning}

Team teachers must discuss the following issues when they are planning together before beginning to teach together to help to prevent conflict later and make the team more efficient at the outset:

- What kind of materials, books and supplies will you choose?

- Which materials are mine, which are yours, and which are ours?

- How can you set aside several hours of joint planning per week?

- Which content should each of us teach?

- What content should be divided?

- What content should be taught jointly?

- How will you keep records? What is the grading system?

- What are the strength and weakness of both team teachers?

-What are the things you have in common?

-What are the things that make you different?

- Do you both have the same level of expertise about the curriculum and instructing students?

- How will you ensure that you both are actively involved and neither feels over- or underutilized?

- What feedback structure can you create to assist in your regular communication?

- How can you ensure that this schedule will be maintained consistently so that both team teachers can trust it?

- How will you maintain communication between team taught sessions?

Additionally, team teachers also need to discuss and then make decisions about the following issues:

- How will you make best use of mutual planning time, how to evaluate progress, grades?

- How will you develop class rules and behavior management?

- How will you communicate with other personnel?

- How will you get to know your partner?

\subsection{Classroom dynamics}

The interactions in a team taught classroom are unique to this teaching arrangement. Team teachers need to discuss the following issues:

- Team teachers should clearly define classroom roles and responsibilities.

- Team teachers' instructional interactions should reflect their professional relationship.

- The curriculum in team-taught classes should explicitly address academic, developmental, and compensatory criteria, and should reflect the needs of students in the class.

- Team teachers should monitor their efforts.

\section{Conclusion}

Team teaching in EFL is a new area to study. It can be an extremely beneficial and professionally rewarding experience if all goes well. In order to team teach successfully, both the CET and NSET need to cooperate and to maintain respect for each other, both inside and outside the classroom. As discussed above, team teachers also need to develop and establish a special relationship, both personally and professionally.

\section{References}

Anderson, L. \& Landy, J. (2006). Team Teaching: Benefits and Challenges. Speaking of Teaching. The Center for Teaching and Learning. Stanford University, 16(1), 1-4.

Collinson, v. (1999). Redefining teacher excellence. Theory into Practice, 38 (1), 4-11.

Davis, J. R. (1995). Interdisciplinary Course and Team Teaching: New Arrangement for Learning. Phoenix: ACE/Oryx. 
Friend, M. \& Cook, L. (2003). Interactions: Collaboration skills for school professionals (4 $4^{\text {th }}$ ed.). New York: Longman.

Ivins, W. H. (1964). Team teaching in the southwestern secondary school. Albuquerque: University of New Mexico, College of Education.

Jacobs, H. H. (1999). Breaking ground in high school integrated curriculum. Reston, VA: National Association of Secondary School Principals..

Quinn, S. \& Karter, S. (1984).Team Teaching: An Alternative to Lecture Fatigue. (JC850 005) Paper in an abstract: Innovation Abstracts (Eric Document Reproductive Service No. ED 251 159).

Sharon, V., Jeanne, S. and Maria, A., (1997). The ABCDEs of Co-Teaching, Teaching Exceptional Children, 30 (2), 4-10.

Robinson, B. \& Schaible, R. 1995. Collaborative teaching: Reaping the benefits. College Teaching, 43 (2), 57-60.

Vars, G. F. (1969). Common learnings: Core and interdisciplinary team approaches. Scranton, PA: International Textbook.

Watkins, K. \& Caffarella, R. (1999).Team Teaching: Face-to-face and On-line. Presentation given at Commisssion of Professors of Adult Education meeting. An Antonio, TX.

York, L. J. (1971). The background, philosophy, and purposes of team teaching. Dallas, TX: Leslie Press 